\title{
原著
}

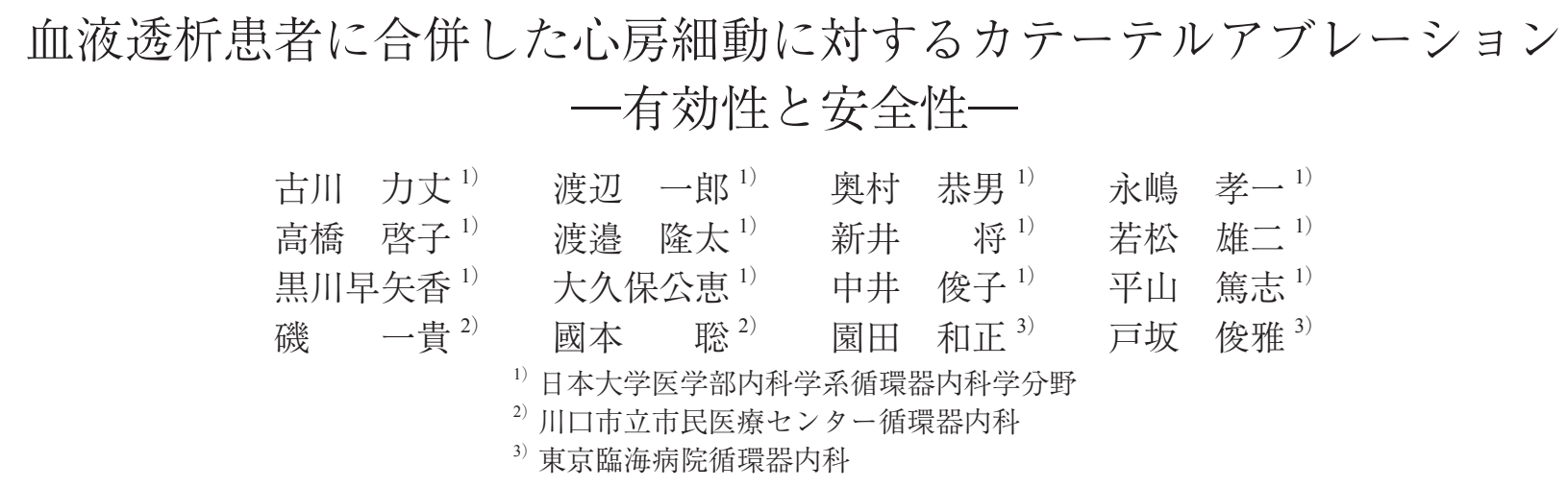

\section{Efficacy and Safety of Catheter Ablation for Atrial Fibrillation in Patients Undergoing Hemodialysis}

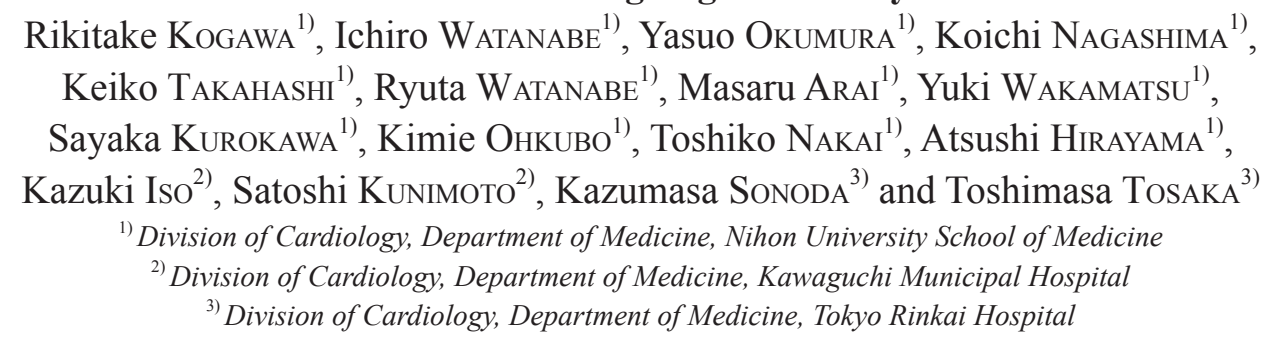

Background: It is well known that the prevalence of atrial fibrillation (AF) increases in chronic renal failure patients undergoing hemodialysis (HD), and that AF often occurs during $\mathrm{HD}$, resulting in hemodynamic instability. It is often difficult to treat AF because of the limited use of anti-arrhythmic drugs. While pulmonary vein isolation (PVI) using an irrigation-tip catheter is a widely accepted therapy for AF, little is known about the effectiveness and complications of PVI in HD patients.

Method and Results: We compared the outcomes and complications between 6 HD patients (age: $64.8 \pm 5.4$ years, 4 men, 2 non-paroxysmal AF patients) and age- and sex-matched non-HD 12 patients (age: $66.2 \pm 5.2$ years, 8 men, 4 non-paroxysmal AF patients) who underwent PVI for AF. In 4 (66\%) of the 6 HD patients, vascular complications ( 2 femoral hematoma and 1 pseudo-aneurysm) and epistaxis requiring blood transfusion occurred after the PVI, but these did not occur in the non-HD patients $(p=0.0197)$. There were no major complications, such as congestive heart failure, cardiac tamponade or cerebral infarction after catheter ablation, in either group. During the follow-up period of $14.6 \pm 9.0$ months, AF recurred in 2 HD patients $(33.3 \%)$, compared with $5(41.7 \%)$ of the non-HD patients during a follow up of $15.0 \pm 13.2$ months $(p=0.3904)$.

Conclusions: Our data demonstrated the comparative efficacy of PVI using irrigation catheters between chronic HD patients and non-HD patients. Minor procedure-related complications, such as vascular complications and bleeding, were more prevalent in HD patients compared with non-HD patients.

Key words: atrial fibrillation, chronic renal failure, hemodialysis, ablation 心房細動, 慢性腎不全, 血液透析, アブレーション

(J. Nihon Univ. Med. Ass., 2019; 78 (1): 27-32)

\footnotetext{
要旨 背景：慢性腎不全に対する血液透析 (HD) 施行 症例には心房細動 (AF) の合併率が高いが，抗不整脈薬 の使用は困難な場合が多い，そこで，著者らは HD 症例 に合併した $\mathrm{AF}$ に対するカテーテルアブレーションの有 効性と問題点につき検討した。
}

対象：AF を合併した HD 6 症例と非 HD 症例の AF 12 症例を対照とし, カテーテルアブレーションを施行し, その成績及び合併症を検討した。

結果 : $\mathrm{AF}$ 再発率は $\mathrm{HD}$ 症では $33.3 \%$, 非 HD 症例は $41.7 \%$ と有意差を認めなかった $(p=0.3904)$. 一方, ア 
ブレーションに伴う合併症は HD 症例で 4 症例（穿刺部 の血腫 2 症例, 仮性動脈瘤 1 症例, 輸血を施行した大量 の鼻出血 1 症例）見られたのに対し，非 HD 症例では見 られなった $(p=0.0197)$.

結語：HD 症例に合併する心房細動に対するカテーテ ルアブレーション治療は非 HD 症例同様に有効な治療手 段であるが，血管合併症には留意する必要が有る。

\section{諸言}

心房細動 (AF) は血液透析 (HD) 患者の 11-23\%に観察 され，その半数以上は発作性である ${ }^{1-4)} . \mathrm{AF}$ を合併した $\mathrm{HD}$ 症例は HD 非合併症例に比べ, 死亡率が高い ${ }^{1,2)}$ 。さ らに，心室応答数の速い心房細動が透析中に出現すると 血圧が低下し, また動悸症状の出現で透析困難と成り得 る。しかしながら， HD 症例に合併する $\mathrm{AF}$ に対しての 抗不整脈薬治療困難である事が多い5)。 AF に対するカ テーテルアブレーション治療は AF に対する標準的治療 として増加しているが ${ }^{(6-8)}$ ，HD 症例に合併した $\mathrm{AF}$ に対 するカテーテルアブレーション治療に関しての報告は少 ない旦11)。今回，著者らは HD 患者に合併した $\mathrm{AF} に$ 対 するカテーテルアブレーションを施行したので，その臨 床経過, 合併症についての後ろ向きの成績を, 文献的考 察を加え報告する。

\section{対象及び方法}

心房細動に対して，2013 年-2015 年の間に経皮的力 テーテルアブレーションを施行した AF を合併した HD 患者 6 症例（発作性 $\mathrm{AF}: 3$ 症例，平均年齢：64.8 5.4 歳, 男性 $: 4$ 症例)。対照症例として, 年齢, 性別をマッ チさせた非弁膜症性 AF 症例 12 症例（平均年齢：66.2 5.2 歳, 男性 : 8 症例）を選択し，アブレーション中の 合併症の発生率, アブレーション後の $\mathrm{AF}$ 再発率を比較 検討した。

\section{肺静脈隔離手技}

全ての症例において, 術前 1 力月以上ワルファリン (PT-INR: 2 ～3) あるいは直接作用型経口抗凝固薬を投 与し，また，術直前に経食道心エコー図を施行し，左房 内血栓の無いことを確認した。抗不整脈薬は術前に半減 期の 5 倍以上の期間中止した。アブレーション手技はデ クスメデトミジン，プロポフォールによる鎮静，フェン タニールによる鎮痛下に施行した。経鼻的 5 極の温度セ ンター付きカテーテル (Esophastar, 日本ライフライン, 東京, 日本）を食道内に留置した。両側大腿静脈, 左側 大腿動脈，右内頸静脈を穿刺後，右内頸静脈より冠静脈 洞へ心腔内除細動用の 20 極電極カテーテル（BeeAT, 日本ライフライン）を挿入し，左右大腿静脈より計 3 本 のロングシース (2 SR0 sheaths and 1 SL1 sheath; St. Jude Medical, St. Paul, MN, USA) を経中隔穿刺法により左房 に挿入した。左側大腿動脈からは大動脈圧を測定した。 左房内に進めたロングシース (SR0, SL1) を通し， 2 本の 10 極リング状の電極カテーテル (Lasso; Biosense Webster, Diamond Bar, CA, USA) を同側上，下の肺静脈に留置し た。さらに SR0 シースより, $3.5 \mathrm{~mm}$ 電極長の生理食塩 水灌流型のアブレーション用電極カテーテル (NaviStar ThermoCool; Biosense Webster) を挿入した。 心房細動が 持続している症例では，心腔内除細動により，洞調律に 戻してから，アブレーションを施行したが，除細動され ない症例あるいは洞調律に戻っても直ぐに $\mathrm{AF}$ が再発す る症例では, $\mathrm{AF}$ 下にアブレーションを施行した。 3 次元 マッピングシステム (CARTO 3; Biosense Webster) ガイド 下に拡大同側肺静脈隔離術を出力 20-35 watt, 30 秒間の 通電を生理食塩水 17-30 ml の灌流下で施行した (Fig. 1). 通電電極温度は最高 $41^{\circ} \mathrm{C}$ までとし，また食道内温度 $41^{\circ} \mathrm{C}$ を限とした。肺静脈隔離後も $\mathrm{AF}$ が持続する症例 では，電気的除細動により洞調律に戻し，洞調律下に左 房一肺静脈間の伝導途絶を確認した。

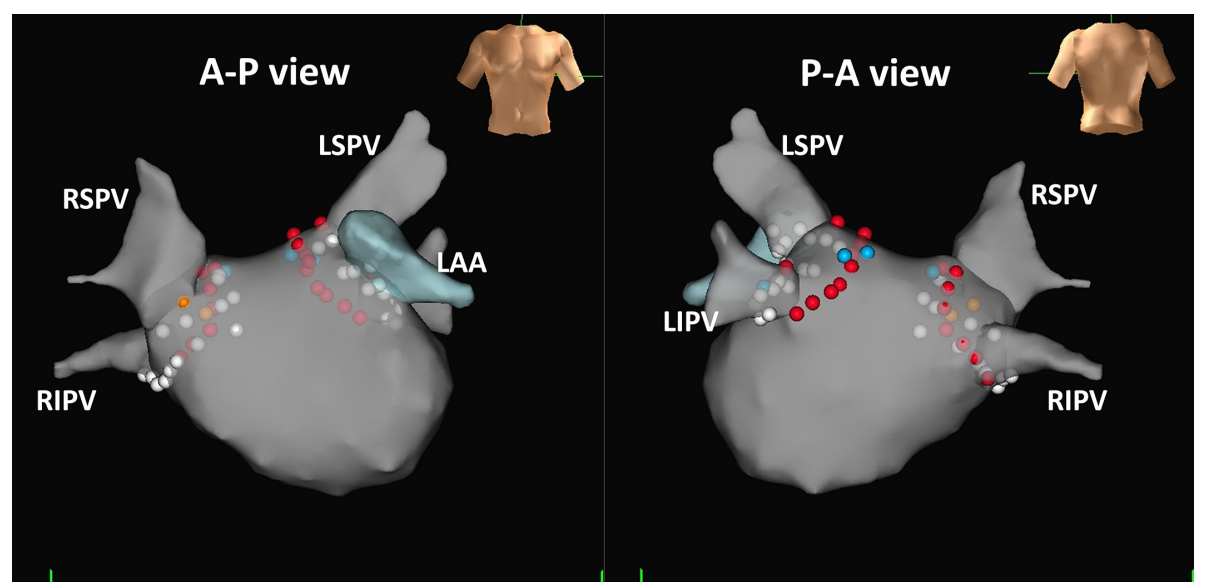

Fig. 1 Schema of the extensive encircled pulmonary vein isolation (EEPVI). Circle points in the schema show ablation points. RSPV: right superior pulmonary vein, RIPV: right inferior pulmonary vein, LSPV: left superior pulmonary vein, LIPV: left inferior pulmonary vein, LAA: left atrial appendage. 


\section{ATP-induced dormant conduction}

肺静脈隔離を確認後，心房，心室順次ペーシング下に ATP $30 \mathrm{mg}$ の急速静脈内投与を施行し, 潜在的な左房一 肺静脈間の伝導の有無を確認し, 潜在伝導が見られた箇 所に対しては，追加通電を施行した ${ }^{12)}$.

複雑分裂心房電位 (complex fractionated atrial electrogram, CFAE) 及び左房線状焼灼

その後，心房頻回刺激法にて 5 分以上持続する $\mathrm{AF}$ に 対しては，左房内の CFAEs および左房線状焼灼 (Fig. 2) を施行した ${ }^{13,14)}$

アブレーション後のフォローアップ

術後 2 日目に退院し，その後，最低3カ月は経口抗凝 固薬を投与した。術前に使用していた抗不整脈薬は術 後3 月月間投与し，その後の使用は外来主治医の判断に 委ねた。術後， 2 週間， 3 力月，6力月，12 力月，その後 は6カ月毎に心電図を記録し，必要に応じて，Holter 心 電図，イベント心電図を追加した。 Primary endpoint と しては，30 秒間以上持続する $\mathrm{AF}$ を $\mathrm{AF}$ の再発と定義 した. Safety endpointとしては, major complication とし て, うっ血性心不全, 心タンポナーデ，脳梗塞， minor complication として，血管合併症，穿刺部よりの出血等
と定義した

\section{統計解析}

症例の臨床上の特徵などの連続変数は mean $\pm \mathrm{SD}$ で, カテゴリー変数は％で表示し，それぞれ，ノンパラメト リック法, フィッシャーの直接確法を用いて検定した。 術後の AF 非再発率は Kaplan-Meier 法を用い，群間比較 は log rank 法を使用した。統計ソフトはJMP 8 software (SAS Institute, Cary, NC, USA) を使用し， $P<0.05$ を有意 差有りと判定した。

\section{結果}

\section{1. 臨床諸指標の比較}

$\mathrm{HD}$ 症例と非 HD 症例の臨床諸指標及び心エコー図 データーを Table 1 に示す. HD 症例で左房径 (LAD) が 有意に大きかったが，その他の指標には有意差を認めな かった

\section{2. カテーテルアブレーションの成績}

$\mathrm{HD}$ 群及び非 HD 群のアブレーション後の $\mathrm{AF}$ 非再発 率を Table 2 に示す。 HD 群と非 HD 群間で，アブレー ションのストラテジーに関しては有意差を認めず, follow-up 期間中の AF 再発率は HD 群で $33 \%(2 / 6)$, 非

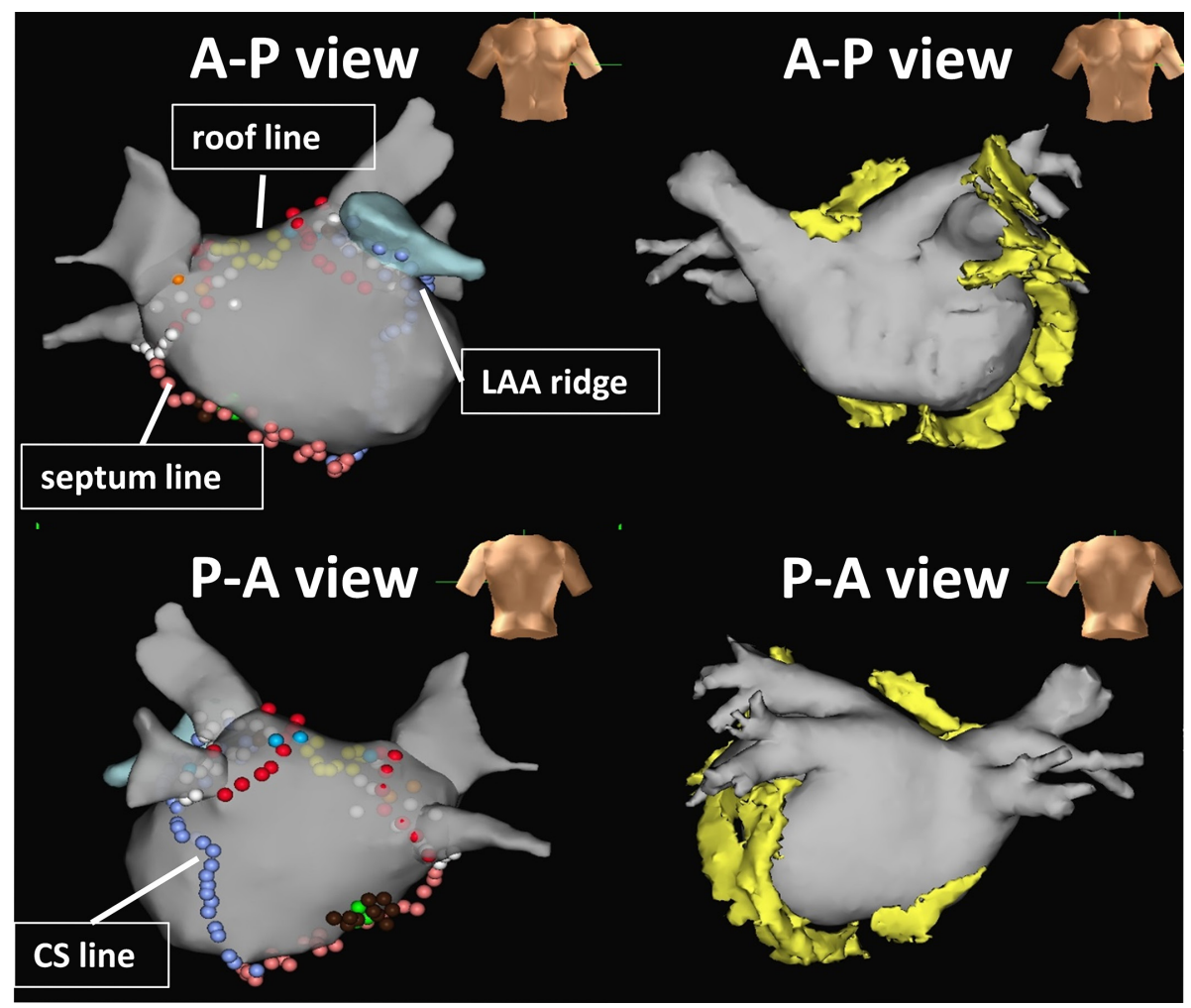

Fig. 2 Schema of the left atrial linear ablation lines. Linear ablations were conducted along the left atrial roof, coronary sinus (CS), left atrial septum and base of the left atrial appendage (LAA). Yellow color at the epicardial side of the left atrium shows left atrial epicardial fat tissue.

A-P: Antero-posterior view, P-A: Postero-anterior view, LAA: left atrial appendage, CS: coronary sinus. 
Table 1 Patient characteristics.

\begin{tabular}{|l|c|c|c|}
\hline & HD group $(\mathrm{n}=6)$ & Non-HD group $(\mathrm{n}=12)$ & $P$-value \\
\hline Age, years & $64.8 \pm 5.4$ & $66.2 \pm 5.2$ & 0.8524 \\
Sex: male & $4(66.6 \%)$ & $8(66.6 \%)$ & 1.0000 \\
Body mass index, $\mathrm{kg} / \mathrm{m}^{2}$ & $24.4 \pm 4.1$ & $22.9 \pm 2.5$ & 0.5139 \\
PAF & $3(50 \%)$ & $6(50 \%)$ & 1.0000 \\
Casual factors & $4(67 \%)$ & $4(33 \%)$ & \\
$\quad$ Hypertension & $4(67 \%)$ & $3(25 \%)$ & 0.2013 \\
Diabetes mellitus & & & 0.1165 \\
TTE parameter & $47.5 \pm 10.5$ & $38.9 \pm 5.5$ & 0.0275 \\
LAD (mm) & $45.6 \pm 5.8$ & $50.0 \pm 4.1$ & 0.2337 \\
LVDd (mm) & $30.9 \pm 6.4$ & $32.0 \pm 7.0$ & 0.6022 \\
LVDs (mm) & $61.8 \pm 8.4$ & $67.3 \pm 12.6$ & 0.2696 \\
LVEF (\%) & & \\
\hline
\end{tabular}

HD: hemodialysis, PAF: paroxysmal atrial fibrillation, TTE: transthoracic echocardiography, LAD: left atrial diameter, LVDd: left ventricular end-diastolic dimension, LVDs: left ventricular end-systolic dimension, LVEF: left ventricular ejection fraction

Table 2 Catheter ablation results.

\begin{tabular}{|l|c|c|c|}
\hline & HD group $(\mathrm{n}=6)$ & non-HD group $(\mathrm{n}=12)$ & $P$ value \\
\hline PVI only & $4(66.6 \%)$ & $5(41.7 \%)$ & $p=0.1523$ \\
PVI + linear ablation & $2(33.3 \%)$ & $7(58.3 \%)$ & $p=0.1523$ \\
PVI + CFAE ablation & $0(0.0 \%)$ & $2(16.7 \%)$ & $p=0.2416$ \\
mean follow-up period (month) & $14.6 \pm 9.0$ & $15.0 \pm 13.2$ & $p=0.7364$ \\
AF recurrence & $2(33.3 \%)$ & $5(41.7 \%)$ & $p=0.3904$ \\
\hline
\end{tabular}

HD: hemodialysis, PVI: pulmonary vein isolation, CFEE: complex fractionated atrial electrogram, AF: atrial fibrillation.

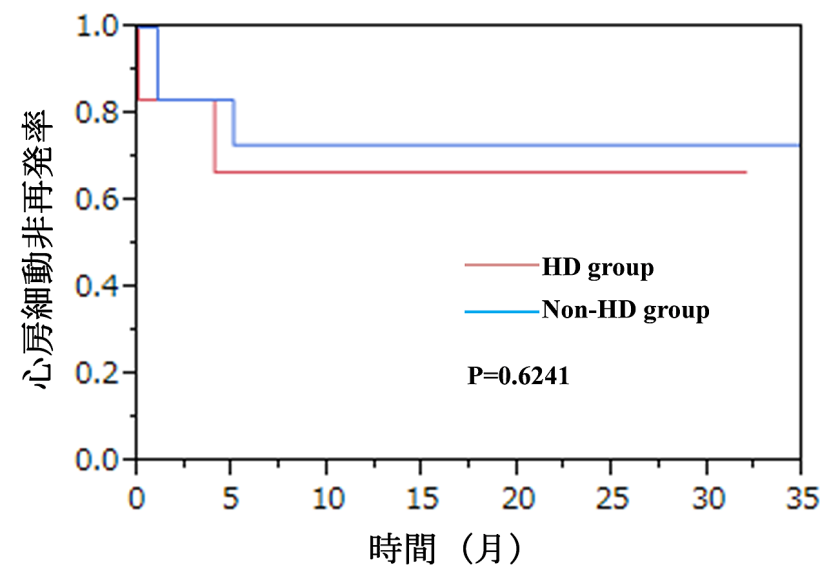

Fig. 3 Kaplan-Meier curve of the non-recurrence of atrial fibrillation after pulmonary vein isolation. HD: hemodialysis,
HD 群で 41.7\% (5/12) と有意差を認めなかった。 KaplanMeier 法での Log rankも P-value $=0.6241$ と有意差を認 めなかった (Fig. 3).

\section{3. 合併症}

PT-INR 及びAPTT 比に合併症有りと無しで有意差を 認めなかったが, HD 群で合併症発生率は有意に高かっ た $(P=0.0197)($ Table 3). Minor complication として, HD 群 6 症例の内, 3 症例で大腿穿刺部の血管合併症（血 腫：2, 仮性動脈瘤：1）を認め, 1 症例では, 食道温度 測定用のカテーテル挿入部側より，大量の鼻出血をきた し，輸血を要した。非 HD 群では minor complication は 認めなかった. Major complication は両群共に認めなかっ た。

Table 3 Comparison between complication patients and no complication patients.

\begin{tabular}{|l|c|c|c|}
\hline & Complication patients $(\mathrm{n}=4)$ & No complication patients $(\mathrm{n}=14)$ & $P$ value \\
\hline PT-INR & $1.01 \pm 0.14$ & $1.31 \pm 0.53$ & $p=0.612$ \\
APTT ratio & $1.13 \pm 0.36$ & $1.09 \pm 0.19$ & $p=0.762$ \\
HD patients & $4(100 \%)$ & $2(14.3 \%)$ & $p=0.0197$ \\
\hline
\end{tabular}

PT-INR: prothrombin time-international normalized ration, APTT: activated partial thromboplastin time, HD: hemodialysis. 


\section{考察}

本研究は $\mathrm{HD}$ 症例に合併した $\mathrm{AF}$ に対するカテーテル アブレーション療法の中期臨床経過及び合併症を非 HD 症例の $\mathrm{AF}$ アブレーションと比較検討した結果を示した ものである。今回の結果では, HD 症例と非 HD 症例間 で，アブレーション後の中期臨床経過には有意差を認 めなかった。しかしながら，HD症例では，術中も血管 系合併症が有意に多かった。透析患者の末梢動脈疾患 罹患率は一般人口と比較し高く。臨床症状による末梢動 脈疾患合併頻度は 15２3\%でみられると報告されてい $b^{15)}$. 従って，カテーテルシース抜去後の穿刺部の止血 には細心の注意が必要である。

慢性腎不全に対する $\mathrm{HD}$ 施行症例に対しての $\mathrm{AF} ア フ ゙$ レーションに関する報告は少ない. SairakuらはHD症 例に合併した発作性 AF30症例に対するカテーテルアブ レーションの成績について, 初回のアブレーション後 $812 \pm 218$ 日の follow-up 期間中， AF 非再発率は，HD 患 者では 54\%，非 HD 患者 $(\mathrm{n}=60)$ では 78\% $(P=0.013)$, また，血管穿刺部よりの出血が $\mathrm{HD}$ 症例では $6.6 \%$, 非 HD 症例では $1.7 \%$ であっと報告している ${ }^{9)}$. Takigawa らはHD患者に合併した発作性 AF32 症例に対するアブ レーションの成績について検討し, 初回アブレーション 後の $\mathrm{AF}$ 非再発率は 1 年後, 3 年後, 5 年後でそれぞれ, $42.3 \% ， 37.6 \% ， 19.7 \%$ であり，非 HD 症例に比べ，有 意に $(P<0.0001)$ に低かったと報告している ${ }^{10)}$. Hayashi らはHD 患者に合併したAF 16 症例（発作性 15 症例） 及び非 $\mathrm{HD}$ 症例の $\mathrm{AF} 111$ 症例（発作性 83 症例）に対す るアブレーションの成績について検討し，初回アブレー ション後の $\mathrm{AF}$ 非再発率は $\mathrm{HD}$ 症例では, 平均 $64.3 \pm$ 20.2 月の follow-up 期間で $25 \%$, 非 HD 症例では 40.5 \%であり，統計的有意差は無かった (Log-rank test $P=$ 0.242 ) と報告している ${ }^{11)}$ 。 上記 3 編の論文共に，本邦よ りの報告であり，海外では， $\mathrm{HD}$ 症例に合併する $\mathrm{AF}$ に 対するアブレーションは制度上，困難な状況にあると推 察される. Ullal らは慢性腎不全を合併した AF 1,593 症 例（HD 症例は 61 例）に対するカテーテルアブレーショ ンの成績，合併症にについて検討し，術後の $\mathrm{AF}$ 非再発 率は慢性腎不全の無い症例と有意差は無く，合併症発生 率についても有意差はみられなかったが，術後，心不全 に基づく再入院は慢性腎不全合併例で多かった ${ }^{16)}$ ，以上 の報告及び著者らの結果より， $\mathrm{HD}$ 症例に合併する $\mathrm{AF}$ に対しても，カテーテルアブレーション治療は有用であ るが, 初回の成功率は非 HD 症例よりも低いとの報告が 多く，複数回のアブレーションが必要となる可能性があ り，また，血管系の合併症が多いことを念頭に置く必要 がある。

\section{本研究の限界}

本研究の限界として, HD 症例の症例数が少ない事が 最大の限界であり, 本研究の成績も踏まえ, 今後, 症例 数の蓄積を考えている。 また，HD症例は対照症例より も左房径が拡大しており，心房の電気的，構造的リモデ リングが進行していることが推察される。それにも拘わ らず，今回の検討では，HD，非 HD 症例での成績に統 計的な差が見られなかった要因としては，症例数が少な い点と, follow-up 期間が比較的短かった点が挙げられ るが，その他の要因として，HD症例においても，肺静 脈隔離術後，誘発した AF が持続した症例に対しては， 積極的にCFAE アブレーション，左房線状焼灼を追加し たことも考えられる。

\section{結語}

$\mathrm{HD}$ 症例に合併する $\mathrm{AF}$ に対するカテーテルアブレー ション治療は非 HD 症例同様に有効な治療手段である が，血管合併症には留意する必要が有る。

本研究には利益相反はありません。

\section{文献}

1) Bozbas H, Atar I, Yildirir A, et al. Prevalence and predictors of arrhythmia in end stage renal disease patients on hemodialysis. Ren Fail 2007; 29: 331-339.

2) Vázquez E, Sánchez-Perales C, Lozano C, et al. Comparison of prognostic value of atrial fibrillation versus SR in patients on long-term hemodialysis. Am J Cardiol 2003; 92: 868-871.

3) Atar I, Konaș D, Açikel S, et al. Frequency of atrial fibrillation and factors related to its development in dialysis patients. Int $J$ Cardiol 2006; 106: 47-51.

4) Tsagalis G, Bakirtzi N, Manios E, et al. Atrial fibrillation in chronic hemodialysis patients: prevalence, types, predictors, and treatment practices in Greece. Artif Organs 2011; 35: 916-922.

5) Zebe H. Atrial fibrillation in dialysis patients. Nephrol Dial Transplant 2000; 15: 765-768.

6) Ouyang F, Bansch D, Ernst S, et al. Complete isolation of left atrium surrounding the pulmonary veins: new insights from the double-Lasso technique in paroxysmal atrial fibrillation. Circulation 2004; 110: 2090-2096.

7) Verma A, Natale A, Padanilam BJ, Prystowsky EN. Why atrial fibrillation ablation should be considered first-line therapy for some patients. Circulation 2005; 112: 1214-1222.

8) Pappone C, Rosanio S, Augello G, et al. Mortality, morbidity, and quality of life after circumferential pulmonary vein ablation for atrial fibrillation: outcomes from a controlled nonrandomized long-term study. J Am Coll Cardiol 2003; 42: 185-197.

9) Sairaku A, Yoshida Y, Kamiya H, et al. Outcomes of atrial fibrillation of paroxysmal atrial fibrillation on chronic hemodialysis. J Cardiovasc Electrophysiol 2012; 23: 1289-1294.

10) Takgawa, Kuwahara T, Takahashi A, et al. The impact of hemodialysis on the outcomes of catheter ablation in patients with paroxysmal atrial fibrillation. Europace 2014; 16: 32: 327-334. 
11) Hayashi M, Kaneko S, Shimano M, et al. Efficacy and safety of radiofrequency catheter ablation for atrial fibrillation in chronic hemodialysis patients. Nephrol Dial Transplant 2014; 29: 10-167.

12) Macle L, Khairy P, Weerasooriya R, et al. Adenosine-guided pulmonary vein isolation for the treatment of paroxysmal atrial fibrillation: an international, multicenter randomized superiority trial. Lancet 2015; 386: 672-679.

13) Nademanee K, McKenzie J, Kosar E, et al. A new approach for catheter ablation: mapping of the electrophysiologic substrate. J Am Coll Cardiol 2004; 43: 2044-2053.
14) Nakahara S, Hori Y, Kobayashi S, et al. Epicardial adipose tissue-based defragmentation approach to persistent atrial fibrillation: its impact on complex fractionated electrogram and the ablation outcome. Heart Rhythm 2014; 11: 1343-1351.

15）社団法人日本透析医学会. 血液透析患者における心血管 合併症の評価と治療に関するガイドライン，透析会誌 2011; 44: 337-425.

16) Ullal AJ, Kaiser DW, Fan J, et al. Safety and clinical outcomes of catheter ablation of atrial fibrillation in patients with chronic kidney disease. J Cardiovasc Electrophysiol 2017; 28: 3948. 